\title{
A novel degradation pathway in the assimilation of phenanthrene by Staphylococcus sp. strain PN/Y via meta-cleavage of 2-hydroxy-1-naphthoic acid: formation of trans-2,3-dioxo-5-(2'-hydroxyphenyl)- pent-4-enoic acid

\author{
Somnath Mallick, Subhankar Chatterjee and Tapan K. Dutta
} \\ Correspondence \\ Tapan K. Dutta \\ tapan@bic.boseinst.ernet.in \\ Received 8 November 2006 \\ Revised 17 January 2007 \\ Accepted 17 January 2007 \\ Department of Microbiology, Bose Institute, Kolkata 700054, India
}

\section{INTRODUCTION}

Polycyclic aromatic hydrocarbons (PAHs) constitute a group of priority environmental pollutants, which are ubiquitous contaminants in soils and sediments and are of environmental concern because of their toxic, mutagenic and/or carcinogenic effects (Mastrangelo et al., 1996; Marston et al., 2001; Xue \& Warshawsky, 2005). In recent years, the biodegradation of PAHs has received considerable attention and a variety of micro-organisms have been reported to play important roles in the process (Pothuluri \& Cerniglia, 1994; Shuttleworth \& Cerniglia, 1995; Kanaly \& Harayama, 2000; Habe \& Omori, 2003; Tortella et al., 2005). Bioremediation technologies have increasingly been proposed to decontaminate $\mathrm{PAH}$-contaminated sites (Harayama, 1997; Samanta et al., 2002; Parrish et al., 2004; Vinas et al., 2005).

Phenanthrene, a PAH with three condensed rings fused in angular fashion, has a 'bay-region' and a 'K-region' and is

Abbreviations: $\mathrm{d}_{6}-\mathrm{DMSO}$, deuterated DMSO; ESI, electrospray ionization; $\mathrm{PAH}$, polycyclicaromatic hydrocarbon.

The GenBank/EMBL/DDBJ accession number for the sequence determined in this study is DQ404012. often used as a model substrate for studies on the metabolism of carcinogenic PAHs. Over the last 60 years, a number of studies on phenanthrene degradation by several Gram-negative and Gram-positive bacterial species have been reported (Evans et al., 1965; Kiyohara et al., 1976, 1982; Kiyohara \& Nagao, 1978; Barnsley, 1983; Gibson \& Subramanian, 1984; Houghton \& Shanley, 1994; Adachi et al., 1999; Samanta et al., 1999), where various pathways and metabolic diversity involved in phenanthrene degradation were documented. In general, the metabolic pathway is initiated by the double hydroxylation of the bay-region of phenanthrene by a dioxygenase enzyme to form cis-3,4-phenanthrenedihydrodiol. The resultant dihydrodiol is then converted by the action of dihydrodiol dehydrogenase to 3,4-dihydroxyphenanthrene, which undergoes meta-cleavage, and in subsequent steps the ring-cleavage product is converted to 1-hydroxy-2naphthoic acid. 1-Hydroxy-2-naphthoic acid is further degraded by one of the two distinct pathways reported so far. In one of the routes, 1-hydroxy-2-naphthoic acid undergoes oxidative decarboxylation to form 1,2-dihydroxynaphthalene, which is subsequently metabolized by the classical naphthalene degradation pathway via salicylic acid and catechol (Evans et al., 1965; Gibson \& 
Subramanian, 1984). In the other route, 1-hydroxy-2naphthoic acid undergoes ring cleavage by 1-hydroxy-2naphthoate dioxygenase in ortho-fashion and is further metabolized via $o$-phthalic acid and protocatechuic acid (Kiyohara et al., 1976; Houghton \& Shanley, 1994; Adachi et al., 1999). Conversion of 1-hydroxy-2-naphthoic acid to 1-naphthol (Pelkonen \& Nebert, 1982; Samanta et al., 1999; Prabhu \& Phale, 2003; Kim et al., 2005) and ortho-cleavage of 1,2-dihydroxynaphthalene to 2-carboxycinnamic acid (Keum et al., 2006) indicated metabolic diversity in phenanthrene degradation pathways. In addition, 1-naphthol is metabolized via either the $o$-phthalate or the salicylate pathway while 2-carboxycinnamic acid is metabolized via the $o$-phthalate pathway.

Apart from dioxygenation of phenanthrene at the 3,4position, there are reports of phenanthrene degradation involving initial dioxygenation at the 9,10-position of phenanthrene (Sutherland et al., 1990; Narro et al., 1992; Moody et al., 2001). In addition, there are a few reports on the assimilation of phenanthrene via initial dioxygenation at the 1,2-position of phenanthrene. Jerina et al. (1976) detected cis-1,2-phenanthrenedihydrodiol as a minor product of phenanthrene degradation in the mutant strains Beijerinckia B-836 and Pseudomonas putida 119. Moreover, dioxygenation at the 1,2-position of phenanthrene by Burkholderia sp., Sphingomonas sp. strain P2, Mycobacterium vanbaalenii PYR-1 and Sinorhizobium sp. C4 has been reported recently (Balashova et al., 1999; Pinyakong et al., 2000; Keum et al., 2006; Kim et al., 2005). These studies revealed that the 1,2-dihydroxyphenanthrene produced in the degradation of phenanthrene was further metabolized to 2-hydroxy-1-naphthoic acid, which was either accumulated as a dead-end metabolite in the culture filtrate or subsequently metabolized by less-characterized minor pathway(s).

Here we report the isolation of a Staphylococcus sp. that can utilize phenanthrene as a sole source of carbon and energy. Furthermore, based on the characterization of metabolites and enzyme activities, a novel phenanthrene degradation pathway, initiated by 1,2-dioxygenation, is described. Phenanthrene is subsequently metabolized to 2-hydroxy1-naphthoic acid, which is further degraded by a novel meta-cleavage dioxygenase, ultimately leading to TCA cycle intermediates via salicylic acid and catechol. We provide a comprehensive report on the microbial degradation of a PAH by a Gram-positive bacterium, describing a distinct ring-cleavage dioxygenase oxidizing between the angular carbon and carboxylated carbon of an $o$-hydroxynaphthoic acid. This study provides new insight into the microbial metabolism of xenobiotics.

\section{METHODS}

Chemicals. Phenanthrene, 2-hydroxy-1-naphthoic acid, 1-naphthol, 2-naphthol, 1,2-dihydroxynaphthalene, salicylic acid, phthalic acid, protocatechuic acid, catechol and deferoxamine mesylate were purchased from Sigma-Aldrich; 1-hydroxy-2-naphthoic acid and pyruvaldehyde were obtained from Nakarai Chemical and Fluka, respectively. Naphthalene-1,2-dicarboxylic acid was synthesized (Fitzgerald et al., 1992) from 1,2-naphthalic anhydride (TCI, Japan). All other chemicals and reagents used in this study were of analytical grade and used without further purification.

Isolation and characterization of bacterial strain. The test organism used in this study (strain $\mathrm{PN} / \mathrm{Y}$ ) was isolated from a petroleum-contaminated soil (Noonmati refinery site, India) by the enrichment culture technique with phenanthrene as the sole source of carbon and energy. Morphological features were studied using a phase-contrast microscope. Conventional biochemical tests were performed using standard methods (Kloos \& Schleifer, 1986; Smibert \& Krieg, 1994). The 16S rRNA gene was amplified using universal bacterial specific primers $\mathrm{f} 27$ and $\mathrm{r} 1492$ (Goodwin et al., 2005) and was sequenced according to the manufacturer's specifications for Taq DNA polymerase-initiated cycle sequencing reactions using fluorescently labelled dideoxynucleotide terminators with an ABI PRISM 377 automated sequencer (Perkin-Elmer Applied Biosystems). The $16 \mathrm{~S}$ rRNA gene sequence of the new isolate was compared against those in the EMBL, GenBank and DDBJ databases using BLAST version 2.2.12 of National Center for Biotechnology Information (Altschul et al., 1990).

Media and culture conditions. Cells were grown in liquid mineral salt medium (MSM, pH 7.0) containing $\left(1^{-1}\right) 3.34 \mathrm{~g} \mathrm{~K}_{2} \mathrm{HPO}_{4}, 0.87 \mathrm{~g}$ $\mathrm{NaH}_{2} \mathrm{PO}_{4}, 2.0 \mathrm{~g} \mathrm{NH} \mathrm{N}_{4} \mathrm{Cl}, 123 \mathrm{mg}$ nitrilotriacetic acid, $200 \mathrm{mg}$ $\mathrm{MgSO}_{4} \cdot 7 \mathrm{H}_{2} \mathrm{O}, 12 \mathrm{mg} \mathrm{FeSO}_{4} \cdot 7 \mathrm{H}_{2} \mathrm{O}, 3 \mathrm{mg} \mathrm{MnSO}_{4} \cdot \mathrm{H}_{2} \mathrm{O}, 3 \mathrm{mg}$ $\mathrm{ZnSO}_{4} \cdot 7 \mathrm{H}_{2} \mathrm{O}$ and $1 \mathrm{mg} \mathrm{CoCl} 2 \cdot 6 \mathrm{H}_{2} \mathrm{O}$. Solid media contained $2 \%$ (w/v) agar (HiMedia, India). Cells were grown at $28{ }^{\circ} \mathrm{C}$ on a rotary shaker (180 r.p.m.) in $100 \mathrm{ml}$ Erlenmeyer flasks containing $25 \mathrm{ml}$ MSM and $1 \mathrm{~g} \mathrm{l}^{-1}$ of either phenanthrene or succinate as sole carbon source, and incubated for different periods of time. To investigate the ability of strain PN/Y to utilize the pathway intermediates, cells were cultivated in MSM in the presence of various substrates (0.1 to $1 \mathrm{~g}$ $1^{-1}$ ) singly as sole carbon sources under identical conditions. For resting cell transformations, cells were harvested in the late exponential phase by centrifugation $(8000 \mathrm{~g}, 10 \mathrm{~min})$, washed twice with an equal volume of potassium phosphate buffer $(50 \mathrm{mM}, \mathrm{pH}$ 7.0) and finally resuspended in the same buffer to give an $\mathrm{OD}_{600}$ of 1.0. Phenanthrene and pathway intermediates in the range of 0.1 to $1 \mathrm{~g}$ $1^{-1}$ were added individually to washed cell suspensions, and incubated at $28{ }^{\circ} \mathrm{C}$ for different periods of time up to $48 \mathrm{~h}$. Unless stated otherwise, each experimental set was performed in triplicate.

Staphylococcus aureus RN4220 (Kreiswirth et al., 1983) was used as bacterial host for plasmid electotransformation and was routinely cultivated at $37{ }^{\circ} \mathrm{C}$ in tryptic soy broth (TSB) medium.

Isolation of metabolites. After incubation, the spent broth and resting cell culture were centrifuged $(8000 \mathrm{~g}, 10 \mathrm{~min})$ and the supernatants were acidified to $\mathrm{pH} 1.5-2.0$ by concentrated hydrochloric acid and extracted three times with an equal volume of ethyl acetate. The combined extracts were dried over anhydrous sodium sulfate and evaporated under reduced pressure. The residues were methylated with a boron trifluoride/methanol solution (Merck) as needed prior to analysis.

Oxygen uptake. Measurements were made at $25{ }^{\circ} \mathrm{C}$ with a YSI model 53 biological oxygen monitor (Yellow Springs Instrument Co.) fitted with a Clark-type oxygen electrode (YSI 5331 oxygen probe). Sample size was $2.0 \mathrm{ml}$, and the reaction mixture contained $500 \mu \mathrm{l}$ cell suspension (25 mg cells, wet weight), substrate $(0.5 \mathrm{ml})$ and $1 \mathrm{ml}$ phosphate buffer $(50 \mathrm{mM}, \mathrm{pH} 7.0)$. The reaction was initiated by injecting a suitable amount of the assay substrate and oxygen uptake was monitored for $5 \mathrm{~min}$. Phenanthrene $(0.5 \mathrm{ml})$ was added as a saturated solution $\left(\sim 1.2 \mathrm{mg} \mathrm{l}^{-1}\right)$, and the possible phenanthrene 
degradation pathway intermediates were added so as to give a final concentration of $0.1 \mathrm{mM}$. The $\mathrm{O}_{2}$ uptake rate was expressed as nmol $\min ^{-1}$ (mg protein $)^{-1}$. The rates were corrected for endogenous oxygen consumption.

Preparation of cell-free extract and enzyme assays. Cells grown in MSM in the presence of phenanthrene $\left(1 \mathrm{~g} \mathrm{l}^{-1}\right)$ were harvested at mid-exponential phase by centrifugation at $8000 \mathrm{~g}$ for $15 \mathrm{~min}$ at $4{ }^{\circ} \mathrm{C}$. The pellet was washed twice with 10 vols $50 \mathrm{mM}$ potassium phosphate buffer ( $\mathrm{pH} 7.0$ ), and resuspended in 2 vols of the same buffer. The cell suspension was ultrasonicated (Labsonic-L, Braun Biotech International) for $6 \mathrm{~min}$ at $4{ }^{\circ} \mathrm{C}$ in 12 pulses and then centrifuged at $20000 \mathrm{~g}$ for $20 \mathrm{~min}$ at $4{ }^{\circ} \mathrm{C}$. The supernatant was used as cell-free enzymes for further studies. Protein was measured by the Lowry method with BSA as the standard.

Spectral determinations. The enzymic transformations of various substrates were carried out by recording cell-free-extract-catalysed changes in UV-visible spectra on a Cary 100 Bio UV-visible spectrophotometer (Varian Australia) using $1 \mathrm{~cm}$ path-length quartz cuvettes. Data were analysed by the Varian Cary Win UV Scan application software.

Chemical analyses. Metabolites obtained from spent cultures and resting cell incubations were resolved by TLC on silica gel $\mathrm{GF}_{254}$ (Merck) plates using benzene: acetic acid (97:3, v/v) as the solvent system. Resolved metabolites were detected by a UV lamp at 254 or $365 \mathrm{~nm}$. The identity of resolved product(s) was occasionally determined by comparison with the TLC profile of reference compounds developed identically.

GC-MS analysis of phenanthrene and its degradation products was performed by using a Varian 3800 GC apparatus with a Saturn-2000 mass spectrometer (Varian) equipped with a $30 \mathrm{~m} \times 0.25 \mathrm{~mm}$ $(0.25 \mu \mathrm{m}$ film thickness) HP-5MS capillary column. The temperature programme gave a $1.5 \mathrm{~min}$ hold at $70{ }^{\circ} \mathrm{C}$, an increase to $200{ }^{\circ} \mathrm{C}$ at $10{ }^{\circ} \mathrm{C} \mathrm{min}{ }^{-1}$, further increase to $280{ }^{\circ} \mathrm{C}$ at $5{ }^{\circ} \mathrm{C} \mathrm{min}{ }^{-1}$ and a $10 \mathrm{~min}$ hold at $280^{\circ} \mathrm{C}$. The injection volume was $1 \mu \mathrm{l}$, and the carrier gas was helium $\left(1.5 \mathrm{ml} \mathrm{min}^{-1}\right)$. The mass spectrometer was operated at an electron ionization energy of $70 \mathrm{eV}$. Probe mass spectra were obtained on a Micromass Q-TOF micromass spectrometer (Waters) using a direct exposure probe and electrospray ionization (ESI).

In addition, the metabolites were resolved by an HPLC system (Waters) on an analytical Inertsil ODS-3 column $(5 \mu \mathrm{m}, 4.6 \times$ $250.0 \mathrm{~mm}$; MetaChem Technologies) equipped with a guard column packed with the same stationary phase and attached to a Waters 515 solvent delivery system. The biodegraded products were eluted with a programmed methanol/water gradient as solvent system at a flow rate of $1.0 \mathrm{ml} \mathrm{min}{ }^{-1}$ and detected by a Waters 486 tunable absorbance UV detector at $254 \mathrm{~nm}$. The mobile phase was a 45 min linear gradient from $50 \%(\mathrm{v} / \mathrm{v})$ to $95 \%(\mathrm{v} / \mathrm{v})$ aqueous methanol with holding at $95 \%$ aqueous methanol for $10 \mathrm{~min}$ followed by $95 \%(\mathrm{v} / \mathrm{v})$ to $50 \%(\mathrm{v} / \mathrm{v})$ aqueous methanol in $5 \mathrm{~min}$. Metabolites were identified by comparing their retention times with those of the authentic compounds analysed under the same set of conditions. For further characterization of metabolites, the organic extracts were resolved by HPLC and the individual components were collected. Fractions of individual components were combined, evaporated under reduced pressure to remove methanol and then lyophilized. The components so separated were tested individually for homogeneity by HPLC, and were subsequently used for mass and NMR analyses.

${ }^{1} \mathrm{H}$ - and ${ }^{13} \mathrm{C}-\mathrm{NMR}$ spectra were obtained with a DRX 500 NMR system (Bruker) operated at 500 and $125 \mathrm{MHz}$, respectively. The intensity of each chemical shift was determined relative to tetramethylsilane as an internal standard; deuterated DMSO $\left(\mathrm{d}_{6}\right.$-DMSO) was used to dissolve each sample.
Plasmid characterizations. For plasmid curing, acridine orange was added at a final concentration of $300 \mu \mathrm{g} \mathrm{ml}^{-1}$ to $\mathrm{LB}$ medium inoculated with about $10^{6}$ exponential-phase cells $\mathrm{ml}^{-1}$. After $24 \mathrm{~h}$ incubation at $37{ }^{\circ} \mathrm{C}$, the culture was diluted with saline and plated on LB-agar plates. The colonies appearing on the plates were replicated onto MSM plates to examine phenanthrene-assimilation activity.

Plasmid DNA was isolated by the alkaline extraction procedure (Birnboim \& Doly, 1979) with slight modification, where lysostaphin was added at a final concentration of $150 \mu \mathrm{g} \mathrm{ml} \mathrm{m}^{-1}$. Electrotransformation of plasmid DNA into S. aureus RN4220 was achieved by the procedure developed by Schenk \& Laddaga (1992); the transformants were screened on MSM-agar plates based on the growth of the colonies utilizing phenanthrene as sole carbon source.

To ascertain the size of the plasmid, plasmid DNA and S1 nucleasetreated plasmid DNA (digested for $1 \mathrm{~h}$ at $37{ }^{\circ} \mathrm{C}$ with $15 \mathrm{U} \mathrm{S} 1$ nuclease) were subjected to PFGE in a Pulsaphor Plus System with a hexagonal electrode array (Pharmacia) in $0.5 \times$ TAE buffer $(20 \mathrm{mM}$ Tris/acetate and $0.5 \mathrm{mM}$ EDTA, $\mathrm{pH} 8.0)$ at $4{ }^{\circ} \mathrm{C}$. The gel was run in $1 \%(\mathrm{w} / \mathrm{v})$ pulsed-field grade agarose (Bio-Rad) with $10 \mathrm{~s}$ basic pulse conditions for $16 \mathrm{~h}$ at $10 \mathrm{~V} \mathrm{~cm}^{-1} . \lambda \mathrm{DNA}$ concatamer and $\lambda \mathrm{DNA} /$ HindIII (New England Biolabs) were used as DNA molecular size markers. After electrophoresis, gels were stained with ethidium bromide followed by destaining in distilled water to visualize the separated DNA, and the data were recorded using a gel documentation system (GelDoc 2000; Bio-Rad).

\section{RESULTS}

\section{Isolation and characterization of strain PN/Y}

Using an enrichment culture technique, a phenanthrenedegrading bacterium, strain $\mathrm{PN} / \mathrm{Y}$, was isolated from petroleum-contaminated soil. The strain was a Grampositive coccus, facultatively anaerobic, catalase-positive, coagulase-positive, oxidase-negative, showing acid production from glycerol and mannitol-positive, non-motile, glucose fermentation positive, susceptible to furazolidone and forming yellow colonies on agar plates. Strain PN/Y grew in the presence of $12 \%(\mathrm{w} / \mathrm{v}) \mathrm{NaCl}$ and the cell wall was found to be largely resistant to lysozyme but lysis occurred with lysostaphin. On the basis of the above characteristics and other morphological, nutritional and biochemical features of the organism (Kloos \& Schleifer, 1986; Smibert \& Krieg, 1994), strain PN/Y was presumed to be a Staphylococcus species. To confirm this identification, the $16 \mathrm{~S}$ rRNA gene sequence (1416 bp) of the isolate was determined and deposited in DDBJ/EMBL/GenBank with the accession no. DQ404012. Analysis of that sequence using BLAST search revealed 98.0 and $97.5 \%$ sequence similarity to Staphylococcus aureus strain MSSA476 and Staphylococcus simiae strain CCM7229, respectively. Thus, at this point, strain $\mathrm{PN} / \mathrm{Y}$ has been identified as belonging to the genus Staphylococcus.

Strain PN/Y could utilize phenanthrene as sole source of carbon and energy; the optimal conditions for growth in MSM ( $\mathrm{pH}$ 7.0) were found to be $28{ }^{\circ} \mathrm{C}$ with $1 \mathrm{~g}$ phenanthrene $1^{-1}$ in shaken culture. However, during growth on phenanthrene, the $\mathrm{pH}$ of the medium fell to as low as 6.1, indicating possible accumulation of various 
transient acidic metabolites with time. Besides phenanthrene, strain PN/Y could utilize 2-hydroxy-1-naphthoic acid, salicylic acid and catechol individually as sole sources of carbon and energy, but 1-hydroxy-2-naphthoic acid, 1naphthol, 2-naphthol and o-phthalic acid did not support growth.

\section{Identification of phenanthrene metabolites}

TLC analysis of the ethyl acetate extracts of the phenanthrene spent medium as well as that of the resting cell incubations with phenanthrene indicated the presence of various polar metabolites in the reaction mixture. Based on the comparison of the $R_{\mathrm{f}}$ values and UV-fluorescence properties of standard compounds, 2-hydroxy-1-naphthoic acid $\left(R_{\mathrm{f}} 0.52\right.$, bluish black, fluorescent), 2-naphthol $\left(R_{\mathrm{f}}\right.$ 0.55 , brownish black, non-fluorescent), salicylic acid $\left(R_{\mathrm{f}}\right.$ 0.49 , blue, fluorescent $)$ and catechol $\left(R_{\mathrm{f}} 0.34\right.$, black, nonfluorescent) were identified as the possible intermediates of the phenanthrene degradation pathway.

Biodegraded products obtained from the organic extracts of the spent culture ( $96 \mathrm{~h}$ ) and resting cell incubation (48 h) with phenanthrene were analysed by GC-MS and the results are summarized in Table 1 . Metabolite $\mathrm{V}$ detected at 13.79 min coeluted with authentic 2-naphthol and was consistent with the typical fragmentation pattern of 2 naphthol. On the other hand, 2-hydroxy-1-naphthoic acid was not detected as such since the compound was decarboxylated under the GC-MS conditions and furnished the typical spectrum of 2-naphthol. This has been verified by using authentic 2-hydroxy-1-naphthoic acid under the GC conditions used. However, the mass spectrum of the methyl ester of one of the bioconverted products (metabolite VI) detected at $15.37 \mathrm{~min}$ had a molecular ion at an $\mathrm{m} / \mathrm{z}$ of 202 and its fragmentation pattern was found to be identical to that of the methyl ester of authentic 2-hydroxy-1-naphthoic acid but different from the relative abundance of ions of the methyl ester of 1hydroxy-2-naphthoic acid.

The mass spectrum of one of the metabolites (metabolite VII, $15.55 \mathrm{~min})$ had the base peak at $\mathrm{m} / \mathrm{z}$ of $212\left(\mathrm{M}^{+}\right)$. Fragment ions at $\mathrm{m} / z$ values of $194\left(\mathrm{M}^{+}-\mathrm{H}_{2} \mathrm{O}\right), 166$ $\left(\mathrm{M}^{+}-\mathrm{H}_{2} \mathrm{O}-\mathrm{CO}\right)$ and $165\left(\mathrm{M}^{+}-\mathrm{H}_{2} \mathrm{O},-\mathrm{CHO}\right)$ are characteristics of cis-phenanthrenedihydrodiol (Moody et al., 2001). Based on the mass fragmentation pattern and comparison of the major ion peaks with that of cis-3,4phenanthrenedihydrodiol and cis-9,10-phenanthrenedihydrodiol (Moody et al., 2001), metabolite VII was tentatively identified as cis-1,2-phenanthrenedihydrodiol. Metabolite IX, detected at 18.32 min with the molecular ion $\left(\mathrm{M}^{+}\right)$at $\mathrm{m} / z 196$ and the major ion products at $\mathrm{m} / z 168\left(\mathrm{M}^{+}-\mathrm{CO}\right)$ and $139\left(\mathrm{M}^{+}-\mathrm{CO},-\mathrm{CHO}\right)$, was identified as 5,6benzocoumarin, similar to the mass spectral data as reported earlier (Pinyakong et al., 2000).

Among others, metabolites I, II and III, detected at 7.49, 8.74 and $9.27 \mathrm{~min}$ with the molecular ions $\left(\mathrm{M}^{+}\right)$at $\mathrm{m} / \mathrm{z}$ 122, 110 and 138, were identified as salicylaldehyde, catechol and salicylic acid, respectively. Two more metabolites, naphthalene 1,2-dicarboxylic acid (metabolite VIII as dimethyl ester) and 2-methoxynaphthalene (metabolite IV), detected at 16.96 and $11.25 \mathrm{~min}$ with the molecular ions at $\mathrm{m} / \mathrm{z} 244$ and 158 , respectively, were assumed to be the dead-end products of the phenanthrene degradation pathway in strain $\mathrm{PN} / \mathrm{Y}$ since none of these compounds were found to be metabolized during resting cell incubation of phenanthrene-grown cells.

Table 1. GC-MS data for the metabolites of phenanthrene obtained from the organic extracts of the spent culture and resting cell incubation of strain $\mathrm{PN} / \mathrm{Y}$

\begin{tabular}{|c|c|c|c|}
\hline Metabolite & $\begin{array}{l}\text { Retention time } \\
\qquad(\mathrm{min})\end{array}$ & $m / z$ of major ion peaks $(\%)^{*}$ & Suggested structure $\dagger$ \\
\hline I & 7.49 & $122\left(\mathrm{M}^{+}, 100\right), 121(92), 104(18), 93(29), 76(27), 65(41)$ & Salicylaldehyde \\
\hline III & 9.27 & $138\left(\mathrm{M}^{+}, 55\right), 120(100), 92(60), 64(26)$ & Salicylic acid \\
\hline IV & 11.25 & $158\left(\mathrm{M}^{+}, 100\right), 143(8), 128(12), 115(83), 89(5), 63(6)$ & 2-Methoxynaphthalene \\
\hline $\mathrm{V}$ & 13.79 & $144\left(\mathrm{M}^{+}, 100\right), 116(24), 115(70), 89(11), 57(11)$ & 2-Naphthol \\
\hline VII & 15.55 & $\begin{array}{l}212\left(\mathrm{M}^{+}, 58\right), 194(41), 181(25), 168(85), 166(100), 165(92), \\
152(36), 151(13), 82(17)\end{array}$ & cis-1,2-Phenanthrenedihydrodiol \\
\hline VIII & 16.96 & $\begin{array}{l}244\left(\mathrm{M}^{+}, 100\right), 213(15), 198(10), 185(32), 170(6), 141(12) \\
126(8), 114(16)\end{array}$ & $\begin{array}{l}\text { Naphthalene-1,2-dicarboxylic acid, } \\
\text { dimethyl ester } \neq\end{array}$ \\
\hline IX & 18.32 & $196\left(\mathrm{M}^{+}, 49\right), 168(100), 139(89), 70(12), 63(15)$ & 5,6-Benzocoumarin \\
\hline
\end{tabular}

*The ion abundance percentages are shown in parentheses.

†Identification was based on the match of mass spectra (fragmentation and peak intensity) and GC retention times with data for authentic samples other than cis-1,2-phenanthrenedihydrodiol and 5,6-benzocoumarin, which were tentatively identified based on their mass spectral data.

\$Analyses were performed after methylation of organic extract with boron trifluoride/methanol. 


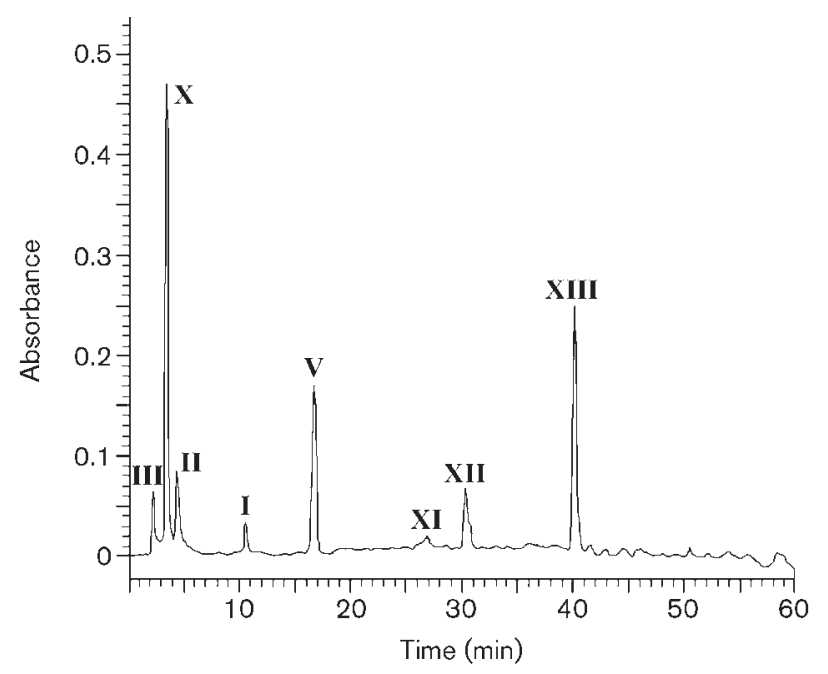

Fig. 1. HPLC profile of phenanthrene and its metabolic intermediates in the culture supernatant during resting-cell transformation of phenanthrene for $48 \mathrm{~h}$ by strain $\mathrm{PN} / \mathrm{Y}$.

On the other hand, HPLC analysis of a phenanthrenedegraded sample showed eight well-resolved peaks (Fig. 1), of which peaks I-III, V, X and XIII were identified as salicylaldehyde, catechol, salicylic acid, 2-naphthol, 2hydroxy-1-naphthoic acid and the unutilized phenanthrene, respectively, by comparing their retention times and co-elution profile with those of the authentic compounds analysed under identical conditions. Fractions collected for peaks $\mathrm{V}$ and $\mathrm{X}$ were further analysed by ${ }^{1} \mathrm{H}$ - and ${ }^{13} \mathrm{C}-\mathrm{NMR}$, thus confirming the identification of the products as 2-naphthol and 2-hydroxy-1-naphthoic acid, respectively. However, the attempt to identify the compound corresponding to the peak XI was unsuccessful due to its low level of production. Peak XII contained a mixture of compounds that co-eluted under the analytical conditions and could not be further separated and characterized by NMR analyses.

\section{Oxygen uptake assay}

The oxidation of metabolic intermediates of phenanthrene by cells grown with phenanthrene, 2-hydroxy-1-naphthoic acid, salicylic acid or succinate as sole carbon source was examined polarographically (Table 2). Cells grown on phenanthrene oxidized 2-hydroxy-1-naphthoic acid, salicylic acid and catechol efficiently but failed to respire on 1hydroxy-2-naphthoic acid, 1,2-dihydroxynaphthalene, naphthalene-1,2-dicarboxylic acid, 1-naphthol, 2-naphthol, $o$-phthalic acid and protocatechic acid. However, cells grown on 2-hydroxy-1-naphthoic acid failed to oxidize phenanthrene, but did oxidize salicylic acid and catechol. On the other hand, cells grown on salicylic acid failed to oxidize both phenanthrene and 2-hydroxy-1-naphthoic acid. Moreover, the immediate activity of the enzymes involved in phenanthrene degradation was not observed with any of the above substrates with succinate-grown cells. It is therefore believed that some of the enzymes involved in the phenanthrene degradation pathway in strain $\mathrm{PN} / \mathrm{Y}$ are inducible.

\section{2-Hydroxy-1-naphthoic acid metabolism}

Metabolism of 2-hydroxy-1-naphthoic acid by the cell-free extract of strain $\mathrm{PN} / \mathrm{Y}$ was demonstrated spectrophotometrically (Fig. 2). The reaction mixture turned slightly

Table 2. Oxygen uptake rates with various compounds by resting-cell suspensions of strain PN/Y grown on different substrates

\begin{tabular}{|c|c|c|c|c|}
\hline \multirow[t]{2}{*}{ Substrate } & \multicolumn{4}{|c|}{$\begin{array}{l}\text { Oxygen uptake rate }\left[\mathrm{nmol} \mathrm{O}_{2} \text { consumed } \min ^{-1}(\mathrm{mg} \text { protein })^{-1}\right]^{*} \\
\text { by cells grown on: }\end{array}$} \\
\hline & Phenanthrene & $\begin{array}{l}\text { 2-Hydroxy-1- } \\
\text { naphthoic acid }\end{array}$ & Salicylic acid & Succinate \\
\hline Phenanthrene & 31 & ND & ND & ND \\
\hline 1,2-Dihydroxynaphthalene & $\mathrm{T}$ & ND & - & - \\
\hline 1-Hydroxy-2-naphthoic acid & ND & ND & - & ND \\
\hline 2-Hydroxy-1-naphthoic acid & 38 & 26 & ND & ND \\
\hline 1-Naphthol & ND & ND & - & - \\
\hline 2-Naphthol & ND & ND & - & - \\
\hline Salicylic acid & 36 & 33 & 34 & ND \\
\hline Catechol & 42 & 40 & 39 & ND \\
\hline$o$-Phthalic acid & ND & ND & - & - \\
\hline Protocatechuic acid & ND & ND & - & - \\
\hline Naphthalene-1,2-dicarboxylic acid & ND & ND & ND & - \\
\hline
\end{tabular}

${ }^{*}$ All values are corrected for the endogenous $\mathrm{O}_{2}$ uptake. ND, Not detectable; -, not measured; $\mathrm{T}$, trace [less than $1 \mathrm{nmol} \mathrm{O}_{2}$ consumed $\min ^{-1}$ (mg protein $\left.)^{-1}\right]$. 


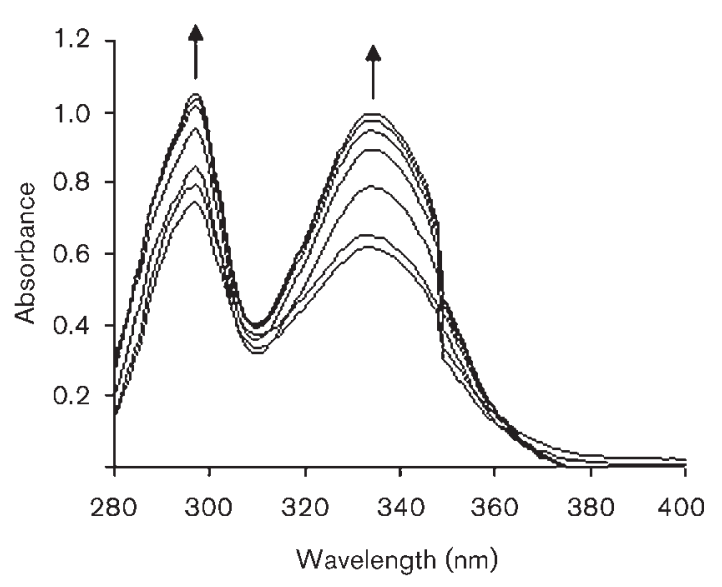

Fig. 2. Spectral changes during metabolism of 2-hydroxy-1naphthoic acid by cell-free extract of phenanthrene-grown cells of strain $\mathrm{PN} / \mathrm{Y}$. The sample and reference cuvettes contained $50 \mathrm{mM}$ potassium phosphate buffer $(\mathrm{pH} 7.0)$ in $1 \mathrm{ml}$ volume. The sample cuvette also contained $50 \mathrm{nmol}$ 2-hydroxy-1-naphthoic acid. Spectra were recorded at $0.25,1,3,5,8,18$ and 33 min after the addition of $200 \mu \mathrm{l}$ extract containing $164.8 \mu \mathrm{g}$ crude protein to both cuvettes. The up arrows indicate increasing absorbance.

yellowish in colour and an increase of absorbance at 297 $\mathrm{nm}$ and $334 \mathrm{~nm}$ was observed when 2-hydroxy-1naphthoic acid was incubated with the crude cell-free extract of strain $\mathrm{PN} / \mathrm{Y}$ grown on phenanthrene, indicating possible ring cleavage of 2-hydroxy-1-naphthoic acid. However, no change in spectral pattern was observed when 1,2-dihydroxynaphthalene was incubated with the cell-free extract of phenanthrene-grown cells. The specific activity of the crude cell-free extract on the transformation of 2-hydroxy-1-naphthoic acid was found to be $0.472 \mathrm{nmol}$ $\min ^{-1}$ (mg protein $)^{-1}$ based on the quantitative estimation of the disappearance of 2-hydroxy-1-naphthoic acid by HPLC. HPLC analysis of the ethyl acetate extract of the cell-free enzyme-mediated transformed products of 2hydroxy-1-naphthoic acid resolved the products into three unknown compounds (XIV, XV and XVI), plus very small amounts of salicylaldehyde (I), catechol (II) salicylic acid (III), 2-naphthol (V) and the unutilized 2-hydroxy-1naphthoic acid (X), as shown in Fig. 3(a). Subsequently, cell-free extract of a 10 litre phenanthrene-grown culture of strain PN/Y was used for the transformation of 2-hydroxy1-naphthoic acid to isolate the major unknown metabolite (XVI) that elutes at $46.58 \mathrm{~min}$ by HPLC. The amount of metabolite XVI isolated was $12 \mathrm{mg}$. However, the attempt to isolate compounds XIV and XV in significant amounts was unsuccessful because of their low level of production. The UV-visible spectrum of metabolite XVI is shown as an inset in Fig. 3(a); ${ }^{1} \mathrm{H}$ - and ${ }^{13} \mathrm{C}-\mathrm{NMR}$ spectral data for freshly prepared solutions of the product in $\mathrm{d}_{6}$-DMSO $(6$ $\mathrm{mg} \mathrm{ml}^{-1}$ ) are shown in Fig. 3(b). Direct-probe ESI-MS analysis in the negative ion mode of metabolite XVI showed a molecular mass of 220 , with the major ions at

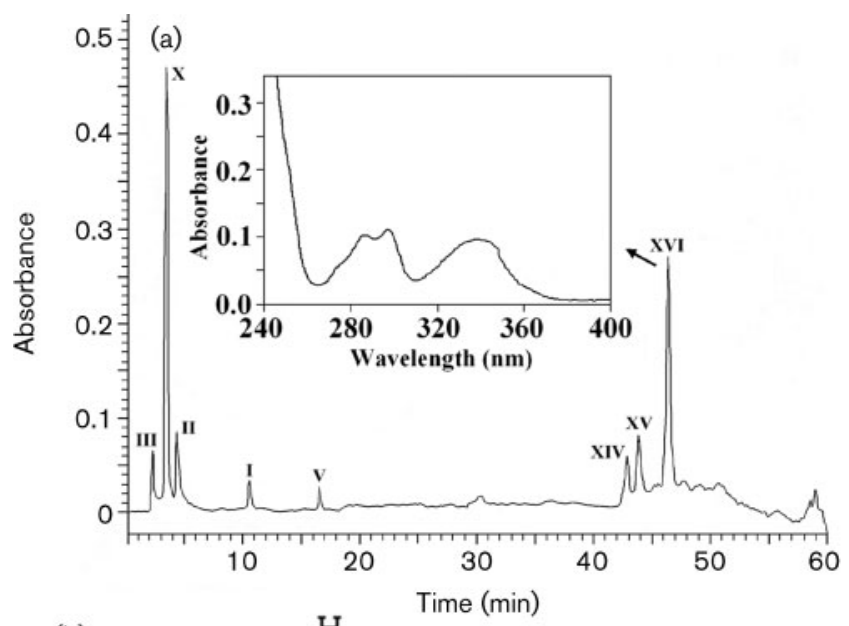

(b)<smiles>Cc1cccc(O)c1/C=C/C(=O)C(=O)C(=O)O</smiles>

trans-2,3-Dioxo-5-(2'-hydroxyphenyl) pent-4-enoic acid

$\begin{array}{llllll}{ }^{1} \mathrm{H} & & { }^{13} \mathrm{C} & { }^{13} \mathrm{C} & \\ \text { a } & 6.76(d), J=16.49 & 1 & 170.09 & 1^{\prime} & 122.24 \\ \text { b } & 7.76(d), J=16.52 & 2 & 192.43 & 2^{\prime} & 158.38 \\ \text { c } & 6.92(d), J=7.43 & 3 & 196.68 & 3^{\prime} & 117.28 \\ \text { d } & 7.18(t), J=7.84,7.55 & 4 & 124.01 & 4^{\prime} & 132.27 \\ \text { e } & 6.79(t), J=7.74,6.84 & 5 & 141.20 & 5^{\prime} & 119.71 \\ \text { f } & 6.52(d), J=7.75 & & & 6^{\prime} & 128.98\end{array}$

Fig. 3. Characterization of transformed products of 2-hydroxy-1naphthoic acid by strain PN/Y in vitro. (a) HPLC profile of 2hydroxy-1-naphthoic acid and its metabolic intermediates formed during transformation of 2-hydroxy-1-naphthoic acid (50 nmol $\left.\mathrm{ml}^{-1}\right)$ by the cell-free extract $\left(164.8 \mu \mathrm{g}\right.$ protein $\left.\mathrm{ml}^{-1}\right)$ of phenanthrene-grown cells of strain PN/Y incubated for $3 \mathrm{~h}$ in a total volume of $2 \mathrm{ml}$. Inset, UV-visible spectrum of the HPLCpurified ring-cleavage product (peak XVI). (b) ${ }^{1} \mathrm{H}$ - and ${ }^{13} \mathrm{C}-\mathrm{NMR}$ data for the ring-cleavage product, trans-2,3-dioxo-5-(2'-hydroxyphenyl)-pent-4-enoic acid (peak XVI) in $d_{6}$-DMSO. Chemical shift (p.p.m.); coupling constant, $J(\mathrm{~Hz})$; d, doublet; t, triplet.

$m / z 219[\mathrm{M}-\mathrm{H}]^{-}$and $175[\mathrm{M}-45]^{-}$. The ${ }^{1} \mathrm{H}-\mathrm{NMR}$ data were consistent with typical trans-oriented olefenic hydrogens as evidenced by the coupling constants of $16.5 \mathrm{~Hz}$. The chemical shifts of $196.68,192.43$ and 170.09 p.p.m. (Fig. 3b) of the isolated compound were typical of two carbonyl carbons and a carboxyl carbon, respectively, consistent with the proposed structure of trans-2,3-dioxo-5(2'-hydroxyphenyl)-pent-4-enoic acid (common name, trans-o-hydroxybenzylideneacetylglyoxylic acid).

Incubation of trans-2,3-dioxo-5-(2'-hydroxyphenyl)-pent4-enoic acid with cell-free extract yielded salicylaldehyde, 
salicylic acid and a trace amount of catechol, indicating it as a pathway intermediate in phenanthrene degradation by strain PN/Y. Thus, it is believed that the ring-cleavage dioxygenase is a meta-cleavage enzyme with respect to the hydroxyl and carboxyl groups of 2-hydroxy-1-naphthoic acid. The initial product is possibly cis-2,3-dioxo-5-(2'hydroxyphenyl)-pent-4-enoic acid that rearranges to give its cyclic isomer, 2-hydroxychromene-2-glyoxylic acid, which on isomerization either spontaneously or enzymically gives trans-2,3-dioxo-5-(2'-hydroxyphenyl)-pent-4enoic acid.

It was observed that the ring-cleavage dioxygenase possessed dissociable ferric iron at the catalytic centre since an increase in the ring-cleavage activity was noticed when the cell-free extract was supplemented with $1 \mathrm{mM}$ $\mathrm{FeCl}_{3}$. This was further verified by the fact that on treatment of the cell-free extract with deferoxamine mesylate, a ferric chelating reagent, the resultant cell-free extract preparation did not show 2-hydroxy-1-naphthoic acid ring-cleavage activity but the ring-cleavage activity could be restored on further treatment with $\mathrm{FeCl}_{3}$ solution. On the other hand, EDTA, a ferrous chelating reagent, had no impact on the enzyme activity.

Cell-free extract obtained from phenanthrene-grown cells showed salicylaldehyde dehydrogenase and catechol-2,3dioxygenase activities. Fig. 4(a) shows cell-free-extractmediated $\mathrm{NAD}^{+}$-dependent conversion of salicylaldehyde to salicylic acid, where an increase in the absorbance at $296 \mathrm{~nm}$ and simultaneous decrease in absorbance at 254 and $330 \mathrm{~nm}$ was observed due to the formation of salicylic acid (Eaton \& Chapman, 1992). Since salicylaldehyde itself has absorbance around $340 \mathrm{~nm}$, formation of NADH $\left(\lambda_{\max }\right.$ at $340 \mathrm{~nm}$ ) from $\mathrm{NAD}^{+}$during this transformation could not be observed during early stage of transformation but became apparent only after 7 min of incubation (Fig. 4a). The presence of meta-cleavage catechol-2,3-dioxygenase activity was confirmed by the appearance of a yellowcoloured product with $\lambda_{\max }$ at $374 \mathrm{~nm}$ (Fig. $4 \mathrm{~b}$ ) due to the formation of 2-hydroxymuconaldehyde acid (Kojima et al., 1961). However, none of these activities could be detected in the cell-free extract obtained from succinate-grown cells.

\section{Plasmid profile}

Neither the genes nor the proteins for aromatic ringhydroxylating dioxygenases have yet been reported for Staphylococcus species, nor did the full genome analysis of various Staphylococcus species present in the database reveal the presence of ring-hydroxylating PAH dioxygenases. This prompted us to look for the presence of catabolic plasmid(s) in strain $\mathrm{PN} / \mathrm{Y}$, and we detected a plasmid which we designated pPHN. To confirm the role of pPHN in phenanthrene metabolism, we examined the correlation of the loss of phenanthrene degradative ability with plasmid removal from strain PN/Y. The plasmidcured strain was unable to grow on either phenanthrene or 2-hydroxy-1-naphthoic acid or salicylic acid as sole carbon
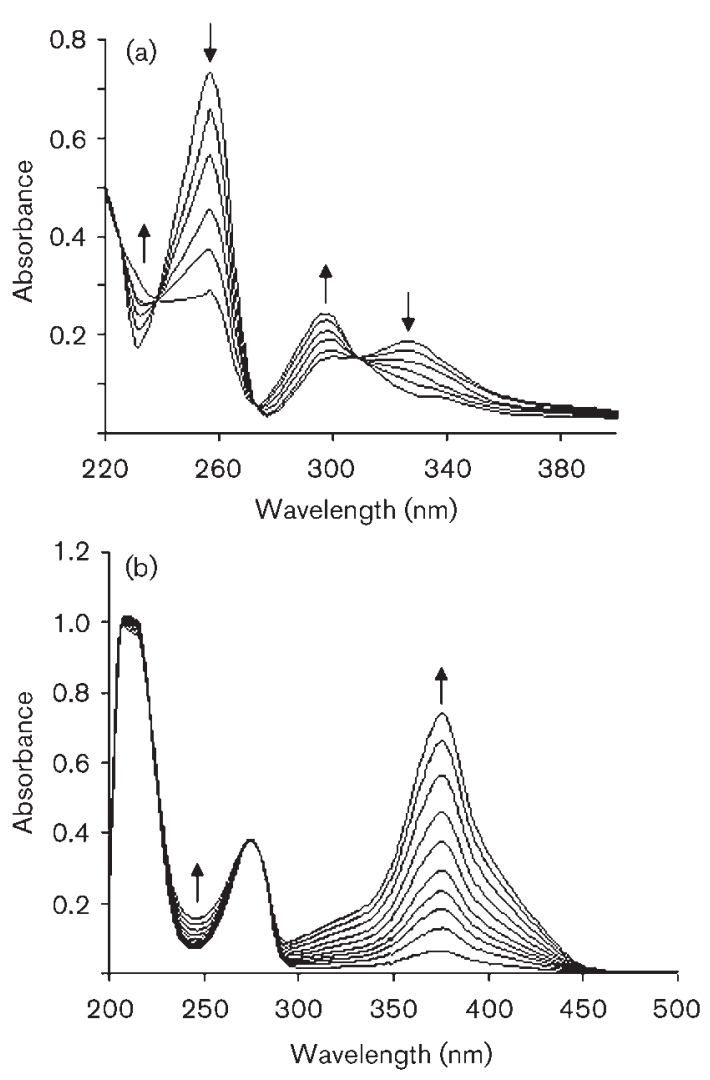

Fig. 4. Spectral changes during metabolism of salicylaldehyde (a) and catechol (b) by cell-free extract of phenanthrene-grown cells of strain PN/Y. The sample and reference cuvettes contained $50 \mathrm{mM}$ potassium phosphate buffer $(\mathrm{pH} \mathrm{7.0})$ in $1 \mathrm{ml}$ volume. The sample cuvette also contained $75 \mathrm{nmol}$ salicylaldehyde (a) and $30 \mathrm{nmol}$ catechol (b). Spectra were recorded at 0.25, 1, 3, 5, 7 and $10 \mathrm{~min}$ after the addition to both cuvettes of $10 \mathrm{nmol} \mathrm{NAD}{ }^{+}$ and $50 \mu \mathrm{l}$ extract containing $41.2 \mu \mathrm{g}$ crude protein for (a) and at $0.25,1,2,3,4,7,10,14,18,22$ and 26 min after the addition to both cuvettes of $25 \mu$ l extract containing $20.6 \mu \mathrm{g}$ of crude protein for (b). The up and down arrows indicate increasing and decreasing absorbance, respectively.

sources, indicating that plasmid pPHN possibly harbours genes involved in phenanthrene assimilation. However, electroporation of pPHN into S. aureus RN4220 enabled the transformant (the yield of transformation was $3.1 \times 10^{3}$ c.f.u. per $\mu \mathrm{g}$ DNA) to metabolize phenanthrene. No differences were observed in the metabolic profile of phenanthrene metabolism by the wild-type strain $\mathrm{PN} / \mathrm{Y}$ and that of S. aureus RN4220 transformed with PPHN.

Separation of intact plasmid DNA extracted from the cells of strain PN/Y by PFGE analysis showed two bands of different intensity (Fig. 5). A similar band pattern in PFGE was also observed from the plasmid DNA isolated from numbers of randomly selected transformants (data not shown). Since the supercoiled forms of large plasmids migrate more slowly than the linear forms and since large, 


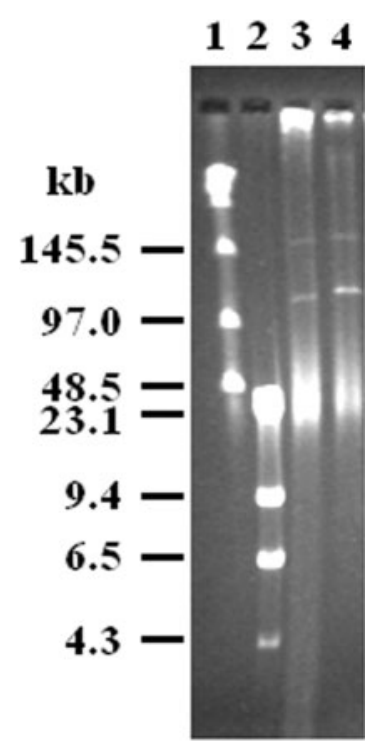

Fig. 5. PFGE pattern of plasmid DNA present in strain PN/Y. Lane 1, $\lambda$ DNA concatamer markers; lane $2, \lambda$ DNA/Hindlll markers; lane 3, pPHN; lane 4, S1 nuclease-treated pPHN.

relaxed circles do not enter the gel when PFGE is used, the two bands observed are believed to be associated with the supercoiled form of a putative megaplasmid and to the linear form, generated by random mechanical linearization (Moreira \& Sa-Correia, 1997 and references therein) under the plasmid isolation conditions used. This was supported by the PFGE analysis of the S1 nuclease-treated plasmid DNA, where a relatively intense band corresponding to the linear form of the megaplasmid was observed (Fig. 5). Based on the mobility of the $\lambda$ DNA markers, the size of the putative linear form of the megaplasmid was estimated to be approximately $112 \mathrm{~kb}$.

\section{DISCUSSION}

Strain PN/Y, isolated from petroleum-contaminated soil, utilizes phenanthrene as sole source of carbon and energy. Although biodegradation of phenanthrene has been widely reported in both Gram-negative and Gram-positive bacteria, very little is known about hydrocarbon degradation ability in the genus Staphylococcus (Mrozik \& Labuzek, 2002; Survery et al., 2004). To the best of our knowledge this is the first report on the metabolic study of a PAH by a Staphylococcus species. Based on the mass, NMR and UVvisible spectral data, a phenanthrene degradation pathway in strain PN/Y is proposed (Fig. 6).

Metabolites accumulating during growth and resting cell incubations with phenanthrene indicate that strain $\mathrm{PN} / \mathrm{Y}$ initiates its attack on phenanthrene by dioxygenation at the $\mathrm{C}-1$ and $\mathrm{C}-2$ positions to give cis-1,2-phenanthrenedihydrodiol (Fig. 6). It is believed that the dehydrogenation of

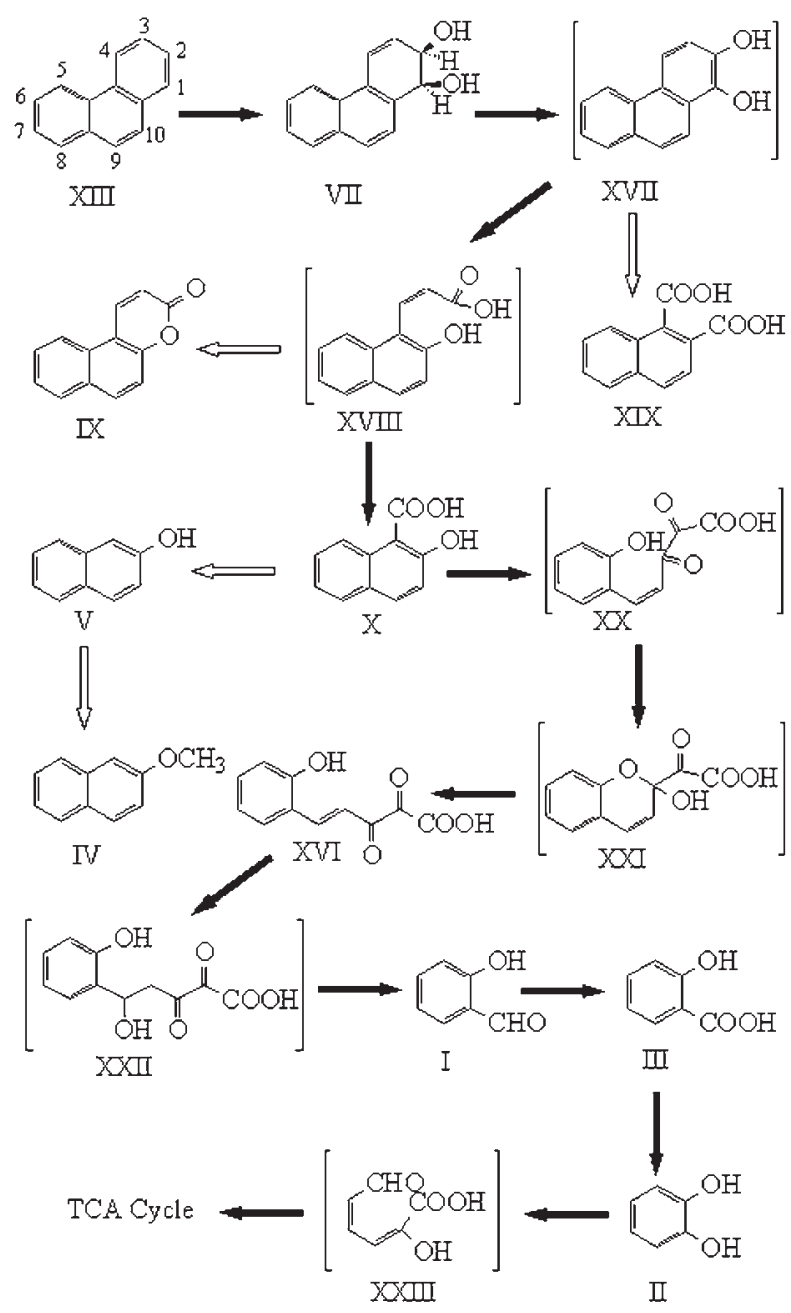

Fig. 6. Proposed pathway for the degradation of phenanthrene by strain $\mathrm{PN} / \mathrm{Y}$. The transient catechol derivatives and some possible intermediates, which were not detected by GC-MS analysis, are shown in brackets. Compound XVI has been characterized by NMR analyses. Filled arrows lead to mineralization; open arrows lead to a dead-end metabolite. Chemical designations: I, salicylaldehyde; II, catechol; III, salicylic acid; IV, 2-methoxynaphthalene; V, 2-naphthol; VII, cis-1,2-phenanthrenedihydrodiol; IX, 5,6-benzocoumarin; X, 2-hydroxy-1-naphthoic acid; XIII, phenanthrene; XVI, trans-2,3-dioxo-5-(2'-hydroxyphenyl)-pent-4enoic acid; XVII, 1,2-dihydroxyphenanthrene; XVIII, cis-2-oxo-4(2'-hydroxynaphthyl)-but-3-enoic acid; XIX, naphthalene-1,2dicarboxylic acid; XX, cis-2,3-dioxo-5-(2'-hydroxyphenyl)-pent-4enoic acid; XXI, 2-hydroxychromene-2-glyoxylic acid; XXII, 2,3-dioxo-5-hydroxy-5-(2'-hydroxyphenyl)-pentanoic acid; XXIII, 2-hydroxymuconaldehyde acid.

cis-1,2-phenanthrenedihydrodiol to the corresponding diol, followed by meta-cleavage of the oxidated ring, yields the identified 2-hydroxy-1-naphthoic acid, while the orthocleavage could yield the identified naphthalene-1,2-dicarboxylic acid. Identification of 5,6-benzocoumarin as one of 
the metabolites supports the enzymic dioxygenation of phenanthrene at the $\mathrm{C}-1$ and $\mathrm{C}-2$ positions and subsequent meta-cleavage of 1,2-dihydroxyphenanthrene. 5,6-Benzocoumarin was reported earlier as one of the compounds produced from phenanthrene-1,2-dihydrodiol (Pinyakong et al., 2000). Although the intradiol cleavage of highmolecular-mass $\mathrm{PAH}$ diols is usually limited to $\mathrm{K}$-region diols (Rehmann et al., 1998; Vila et al., 2001), there are reports on intradiol cleavage of the non-K region diol of PAHs (Dean-Ross et al., 2001; Rehmann et al., 2001; Keum et al., 2006; Kim et al., 2005; Lopez et al., 2006). Naphthalene-1,2-dicarboxylic acid identified in this study was found to be a dead-end metabolite and was not degraded further by strain PN/Y. No other metabolites corresponding to the dioxygenation at the C-3 and C-4 positions or the C-9 and C-10 positions were detected, which may rule out the possible involvement of other upper pathway(s) of phenanthrene metabolism in strain $\mathrm{PN} / \mathrm{Y}$.

Among the possible metabolic intermediates in the degradation of phenanthrene, 2-hydroxy-1-naphthoic acid and salicylic acid were found to be utilized individually by strain $\mathrm{PN} / \mathrm{Y}$. On the other hand, the cells grown on phenanthrene, 2-hydroxy-1-naphthoic acid or salicylic acid failed to respire on 1-hydroxy-2-naphthoic acid, 1,2dihydroxynaphthalene, naphthalene-1,2-dicarboxylic acid or $o$-phthalic acid, indicating that none of these compounds are involved in the phenanthrene degradation pathway. Moreover, oxygen uptake studies revealed that some of the enzymes involved in the assimilation of phenanthrene by strain PN/Y are inducible.

Although assimilation of phenanthrene via 2-hydroxy-1naphthoic acid was reported by Pinyakong et al. (2000), the authors were unable to detect 2-hydroxy-1-naphthoic acid as a metabolic intermediate. However, the identification of coumarin as a product in resting cell transformation with 2-hydroxy-1-naphthoic acid encouraged the authors to hypothesize the metabolic pathway via 1,2-dihydroxynaphthalene and salicylic acid in phenanthrene degradation. On the other hand, Keum et al. (2006) reported 2hydroxy-1-naphthoic acid as one of the metabolic intermediates along with 1-hydroxy-2-naphthoic acid in the degradation of phenanthrene by a Sinorhizobium sp. However, the involvement of 2-hydroxy-1-naphthoic acid in phenanthrene assimilation was revealed from the decrease in concentration of 2-hydroxy-1-naphthoic acid or its precursor in spent culture with time. But no attempt had been made to use 2-hydroxy-1-naphthoic acid as growth substrate or in a resting cell assay to confirm its involvement in the phenanthrene degradation pathway. Similarly, Balashova et al. (1999) reported the accumulation of 1-hydroxy-2-naphthoic acid and 2-hydroxy-1naphthoic acid as the major metabolites in phenanthrene metabolism in Pseudomonas and Burkholderia spp., but the authors were unable to examine the pathway involved in the metabolism of 2-hydroxy-1-naphthoic acid. Recently, 1-hydroxy-2-naphthoic acid and 2-hydroxy-1-naphthoic acid were reported to be identified as metabolic intermediates in the degradation of phenanthrene by Burkholderia sp. C3 and Arthrobacter sp. P1-1 (Seo et al., 2006a, b), which were found to be converged to 1,2-dihydroxynaphthalene and further degraded by ortho- and metacleavage dioxygenases.

In the present study, metabolism of 2-hydroxy-1-naphthoic acid yielded salicylaldehyde, salicylic acid, catechol and a trace amount of 2-naphthol in the spent culture. Although salicylaldehyde, salicylic acid and catechol were also produced as intermediates in the metabolism of 1hydroxy-2-naphthoic acid via 1,2-dihydroxynaphthalene (Evans et al., 1965; Gibson \& Subramanian, 1984), the latter compound neither supported oxygen uptake in the resting cells assay nor was metabolized by the cell-free extracts of phenanthrene- or 2-hydroxy-1-naphthoic acidgrown cells of strain PN/Y, indicating absence of such a metabolic pattern of 2-hydroxy-1-naphthoic acid in this study.

On the other hand, cell-free extracts of phenanthrenegrown cells transformed 2-hydroxy-1-naphthoic acid to give a slightly yellow-coloured reaction mixture. The spectral changes in the UV-visible region were consistent with ring-cleavage activity. Among others, HPLC analysis of the cell-free extract-mediated transformed products of 2-hydroxy-1-naphthoic acid yielded a meta-cleavage product, which was subsequently characterized as trans-2,3dioxo-5-(2'-hydroxyphenyl)-pent-4-enoic acid by NMR analyses (Fig. 3b). Thus from the above observations it is evident that the 2-hydroxy-1-naphthoate dioxygenase is a meta-cleavage enzyme with respect to the carboxylated and hydroxylated carbons and cleaves the aromatic ring between the C-9 and C-1 positions of 2-hydroxy-1naphthoic acid. Moreover, the 2-hydroxy-1-naphthoate dioxygenase, a meta-cleavage enzyme present in the cellfree extract, has dissociable ferric ion as the cofactor in contrast to ferrous ion for 1-hydroxy-2-naphthoate dioxygenase and gentisate dioxygenase, which are involved in ortho-cleavage (Harpel \& Lipscomb, 1990; Adachi et al., 1999).

In the present study, 2-naphthol was detected as a minor metabolite, being the decarboxylated product of 2hydroxy-1-naphthoic acid. A similar decarboxylated product, 1-naphthol from 1-hydroxy-2-naphthoic acid, was reported earlier (Pelkonen \& Nebert, 1982; Samanta et al., 1999; Prabhu \& Phale, 2003; Kim et al., 2005). We observed that 2-naphthol was toxic to strain PN/Y; the minimum growth inhibitory concentration was found to be $45 \mathrm{mg}$ $1^{-1}$. Toxicity of 2 -naphthol has also been reported in Burkholderia and Pseudomonas spp. (Balashova et al., 1999). In addition, a trace amount of 2-methoxynaphthalene, a dead-end product that was detected in the spent culture, was possibly produced by catechol-O-methyltransferase activity of strain PN/Y against the toxic 2-naphthol. It has been reported earlier that the toxicity of non-bay- and non-K-region catechols can be reduced by a constitutive 
catechol-O-methyltransferase activity, since the $O$-methylated derivatives of 1,2-dihydroxyphenanthrene and 1,2dihydroxypyrene prevent the redox cycling between catechol and quinone compounds which generates reactive oxygen species (Kim et al., 2004). Thus, the formation of 2-methoxynaphthalene by strain PN/Y may serve to detoxify the 2-naphthol formed in the degradation process.

We believe that this account of the degradation of phenanthrene by strain $\mathrm{PN} / \mathrm{Y}$ is the first comprehensive study involving the metabolic intermediate 2-hydroxy-1naphthoic acid, which undergoes further degradation by a novel meta-cleavage dioxygenase in the assimilation of phenanthrene (Fig. 6). Considering that none of the Staphylococcus species is so far reported to possess the genetic makeup for ring hydroxylating dioxygenase in PAHs metabolism, it is imperative to understand the genetic features of phenanthrene-assimilating ability in strain PN/Y, identified as a member of the genus Staphylococcus. Interestingly, strain $\mathrm{PN} / \mathrm{Y}$ harbours a catabolic plasmid, pPHN (approx. $112 \mathrm{~kb}$ in size), containing genes for phenanthrene assimilation. Involvement of this megaplasmid in the degradation of phenanthrene was confirmed by the absence of phenanthrene-degradation ability of a plasmid-cured strain and the presence of this activity in $S$. aureus RN4220 electrotransformed with pPHN. Plasmidmediated degradation of many aromatic hydrocarbons including phenanthrene has already been described in the literature and it is understood that horizontal gene transfer of catabolic genes plays a significant role in the acclimatization of microbial communities to pollutants (Guerin \& Jones, 1988; Kiyohara et al., 1990; Herrick et al., 1997; Tsuda et al., 1999; Ma et al., 2006). Thus, horizontal transfer of the catabolic plasmid may be the event by which strain PN/Y acquired PAH-metabolizing ability. Further investigation of the exact taxonomic position of strain $\mathrm{PN} /$ $\mathrm{Y}$, involvement of the catabolic plasmid, cloning and characterization of novel catabolic genes and purification of key enzymes will allow us to better understand this unique phenanthrene degradation pathway in this Staphylococcus strain.

\section{ACKNOWLEDGEMENTS}

Financial support for this work was provided by the Bose Institute, Kolkata, India. S. M. and S. C. were supported with fellowships from the Council of Scientific and Industrial Research, Government of India and Bose Institute, respectively. We gratefully acknowledge S. Sau for providing the strain Staphylococcus aureus RN4220 and R. Bhadra for help in PFGE analysis. We are grateful to Professor K. P. Das for reviewing the manuscript.

\section{REFERENCES}

Adachi, K., Iwabuchi, T., Sano, H. \& Harayama, S. (1999). Structure of the ring cleavage product of 1-hydroxy-2-naphthoate, an intermediate of the phenanthrene-degradative pathway of Nocardioides sp. strain KP7. J Bacteriol 181, 757-763.
Altschul, S. F., Gish, W., Miller, W., Myers, E. W. \& Lipman, D. J. (1990). Basic local alignment search tool. J Mol Biol 215, 403-410.

Balashova, N. V., Kosheleva, I. A., Golovchenko, N. P. \& Boronin, A. M. (1999). Phenanthrene metabolism by Pseudomonas and Burkholderia strains. Process Biochem 35, 291-296.

Barnsley, E. A. (1983). Phthalate pathway of phenanthrene metabolism: formation of 2'-carboxybenzalpyruvate. J Bacteriol 154, 113-117.

Birnboim, H. C. \& Doly, J. A. (1979). A rapid alkaline procedure for screening recombinant plasmid DNA. Nucleic Acids Res 7, 1513-1523.

Dean-Ross, D., Moody, J. D., Freeman, J. P., Doerge, D. R. \& Cerniglia, C. E. (2001). Metabolism of anthracene by a Rhodococcus species. FEMS Microbiol Lett 204, 205-211.

Eaton, R. W. \& Chapman, P. J. (1992). Bacterial metabolism of naphthalene: construction and use of recombinant bacteria to study ring cleavage of 1,2-dihydroxynaphthalene and subsequent reactions. J Bacteriol 174, 7542-7554.

Evans, W. C., Fernley, H. N. \& Griffiths, E. (1965). Oxidative metabolism of phenanthrene and anthracene by soil pseudomonads: the ring fission mechanism. Biochem J 95, 819-831.

Fitzgerald, L. J., Gallucci, J. C. \& Gerkin, R. E. (1992). 1,2Naphthalenedicarboxylic acid: structures of channel clathrates and an unsolvated crystalline phase. Acta Crystallogr B 48, 290-297.

Gibson, D. T. \& Subramanian, V. (1984). Microbial degradation of aromatic hydrocarbons. In Microbial Degradation of Organic Compounds, pp. 181-252. Edited by D. T. Gibson. New York: Dekker.

Goodwin, K. D., Tokaczyk, R., Stephens, F. C. \& Saltzman, E. S. (2005). Degradation of toluene inhibition of methyl bromide biodegradation in seawater and isolation of a marine toluene oxidizer that degrades methyl bromide. Appl Environ Microbiol 71, 3495-3503.

Guerin, W. F. \& Jones, G. E. (1988). Mineralization of phenanthrene by a Mycobacterium sp. Appl Environ Microbiol 54, 937-944.

Habe, H. \& Omori, T. (2003). Genetics of polycyclic aromatic hydrocarbon metabolism in diverse aerobic bacteria. Biosci Biotechnol Biochem 67, 225-243.

Harayama, S. (1997). Polycyclic aromatic hydrocarbon bioremediation design. Curr Opin Biotechnol 8, 268-273.

Harpel, M. R. \& Lipscomb, J. D. (1990). Gentisate 1,2-dioxygenase from Pseudomonas. Purification, characterization, and comparison of the enzymes from Pseudomonas testosteroni and Pseudomonas acidovorans. J Biol Chem 265, 6301-6311.

Herrick, J. B., Stuart-Keil, K. G., Ghirose, N. C. \& Madsen, E. L. (1997). Natural horizontal transfer of a naphthalene dioxygenase gene between bacteria native to a coal tar-contaminated field site. Appl Environ Microbiol 63, 2330-2337.

Houghton, J. E. \& Shanley, M. S. (1994). Catabolic potential of pseudomonads: a regulatory perspective. In Biological Degradation and Bioremediation of Toxic Chemicals, pp. 11-32. Edited by R. G. Chaudhry. London: Chapman \& Hall.

Jerina, D. M., Selander, H., Yagi, H., Wells, M. C., Davey, J. F., Mahadevan, V. \& Gibson, D. T. (1976). Dihydrodiols from anthracene and phenanthrene. J Am Chem Soc 98, 5988-5996.

Kanaly, R. A. \& Harayama, S. (2000). Biodegradation of high molecular weight polycyclic aromatic hydrocarbons by bacteria. $J$ Bacteriol 182, 2059-2067.

Keum, Y. S., Seo, J. S., Hu, Y. \& Li, Q. X. (2006). Degradation pathways of phenanthrene by Sinorhizobium sp. C4. Appl Microbiol Biotechnol 71, 935-941.

Kim, Y. H., Moody, J. D., Freeman, J. P., Brezna, B., Engesser, K. H. \& Cerniglia, C. E. (2004). Evidence for the existence of PAH-quinone reductase and catechol-O-methyltransferase in Mycobacterium vanbaalenii PYR-1. J Ind Microbiol Biotechnol 31, 507-516. 
Kim, Y. H., Freeman, J. P., Moody, J. D., Engesser, K. H. \& Cerniglia, C. E. (2005). Effects of $\mathrm{pH}$ on the degradation of phenanthrene and pyrene by Mycobacterium vanbaalenii PYR-1. Appl Microbiol Biotechnol 67, 275-285.

Kiyohara, H. \& Nagao, K. (1978). The catabolism of phenanthrene and naphthalene by bacteria. J Gen Microbiol 105, 69-75.

Kiyohara, H., Nagao, K. \& Nomi, R. (1976). Degradation of phenanthrene through o-phthalate by an Aeromonas sp. Agric Biol Chem 40, 1075-1082.

Kiyohara, H., Nagao, K., Kouno, K. \& Yano, K. (1982). Phenanthrenedegrading phenotype of Alcaligenes faecalis AFK2. Appl Environ Microbiol 43, 458-461.

Kiyohara, H., Takizawa, N., Data, H., Torigoe, S. \& Yano, K. (1990). Characterization of a phenanthrene degradation plasmid from Alcaligenes faecalis AFK2. J Ferment Bioeng 69, 54-56.

Kloos, W. E. \& Schleifer, K. H. (1986). Genus IV. Staphylococcus Rosenbach 1884, $18^{\mathrm{AL}}$, Nom. Cons. Opin. 17 Jud. Comm. 1958, 153. In Bergey's Manual of Systematic Bacteriology, vol. 2, pp. 1013-1035. Edited by P. H. A. Sneath, N. S. Mair, M. E. Sharpe \& J. G. Holt. Baltimore: Williams \& Wilkins.

Kojima, Y., Itada, N. \& Hayaishi, O. (1961). Metapyrocatachase: a new catechol-cleaving enzyme. J Biol Chem 236, 2223-2228.

Kreiswirth, B. N., Lofdahl, S., Belley, M. J., O'Reilly, M., Shlievert, P. M., Bergdoll, M. S. \& Novick, R. P. (1983). The toxic shock syndrome exotoxin structural gene is not detectably transmitted by a prophage. Nature 305, 709-712.

Lopez, Z., Vila, J., Minguillon, C. \& Grifoll, M. (2006). Metabolism of fluoranthene by Mycobacterium sp. strain AP1. Appl Microbiol Biotechnol 70, 747-756.

Ma, Y., Wang, L. \& Shao, Z. (2006). Pseudomonas, the dominant polycyclic aromatic hydrocarbon-degrading bacteria isolated from Antarctic soils and the role of large plasmids in horizontal gene transfer. Environ Microbiol 8, 455-465.

Marston, C. P., Pereira, Z. C., Ferguson, J., Fischer, L., Hedstrom, O., Dashwood, W. M. \& Baird, W. M. (2001). Effect of a complex environmental mixture from coal tar containing polycyclic aromatic hydrocarbons $(\mathrm{PAH})$ on tumor initiation, PAH-DNA binding and metabolic activation of carcinogenic $\mathrm{PAH}$ in mouse epidermis. Carcinogenesis 22, 1077-1086.

Mastrangelo, G., Fadda, E. \& Marzia, V. (1996). Polycyclic aromatic hydrocarbons and cancer in man. Environ Health Perspect 104, 1166-1170.

Moody, J. D., Freeman, J. P., Doerge, D. R. \& Cerniglia, C. E. (2001). Degradation of phenanthrene and anthracene by cell suspensions of Mycrobacterium sp. strain PYR-1. Appl Environ Microbiol 67, 1476-1483.

Moreira, L. M. \& Sa-Correia, I. (1997). Megaplasmids in Thermus oshimai isolates from two widely separated geographical areas: restriction fragment profiling and DNA homology. Arch Microbiol 168, 473-479.

Mrozik, A. \& Labuzek, S. (2002). A comparison of biodegradation of phenol and homologous compounds by Pseudomonas vesicularis and Staphylococcus sciuri strains. Acta Microbiol Pol 51, 367-378.

Narro, M. L., Cerniglia, C. E., Baalen, C. V. \& Gibson, D. T. (1992). Metabolism of phenanthrene by the marine cyanobacterium Agmenellum quadruplicatum PR-6. Appl Environ Microbiol 58, 1351-1359.

Parrish, Z. D., Banks, M. K. \& Schwab, A. P. (2004). Effectiveness of phytoremediation as a secondary treatment for polycyclic aromatic hydrocarbons (PAHs) in composted soil. Int J Phytoremediation 6, $119-137$.
Pelkonen, O. \& Nebert, D. W. (1982). Metabolism of polycyclic hydrocarbons: etiologic role in carcenogenesis. Pharmacol Rev 34, 189-222.

Pinyakong, O., Habe, H., Supaka, N., Pinpanichkarn, P., Juntongjin, K., Yoshida, T., Furihata, K., Nojiri, H., Yamane, H. \& Omori, T. (2000). Identification of novel metabolites in the degradation of phenanthrene by Sphingomonas sp. strain P2. FEMS Microbiol Lett 191, 115-121.

Pothuluri, J. V. \& Cerniglia, C. E. (1994). Microbial metabolism of polycyclic aromatic hydrocarbons. In Biological Degradation and Bioremediation of Toxic Chemicals, pp. 92-124. Edited by R. G. Chaudhry. London: Chapman \& Hall.

Prabhu, Y. \& Phale, P. S. (2003). Biodegradation of phenanthrene by Pseudomonas sp. strain PP2: novel metabolic pathway, role of biosurfactant and cell surface hydrophobicity in hydrocarbon assimilation. Appl Microbiol Biotechnol 61, 342-351.

Rehmann, K., Noll, H. P., Steinberg, C. E. W. \& Kettrup, A. A. (1998). Pyrene degradation by Mycobacterium sp. strain KR2. Chemosphere 36, 2977-2992.

Rehmann, K., Hertkorn, N. \& Kettrup, A. A. (2001). Fluoranthene metabolism in Mycobacterium sp. strain KR20: identity of pathway intermediates during degradation and growth. Microbiology 147, 2783-2794.

Samanta, S. K., Chakraborti, A. K. \& Jain, R. K. (1999). Degradation of phenanthrene by different bacteria: evidence for novel transformation sequences involving the formation of 1-naphthol. Appl Microbiol Biotechnol 53, 98-107.

Samanta, S. K., Singh, O. V. \& Jain, R. K. (2002). Polycyclic aromatic hydrocarbons: environmental pollution and bioremediation. Trends Biotechnol 20, 243-248.

Schenk, S. \& Laddaga, R. A. (1992). Improved method for electroporation of Staphylococcus aureus. FEMS Microbiol Lett 94, 133-138.

Seo, J. S., Keum, Y. S., Hu, Y., Lee, S. E. \& Li, Q. X. (2006a). Degradation of phenanthrene by Burkholderia sp. C3: initial 1,2- and 3,4-dioxygenation and meta- and ortho-cleavage of naphthalene-1,2diol. Biodegradation 18, 123-131.

Seo, J. S., Keum, Y. S., Hu, Y., Lee, S. E. \& Li, Q. X. (2006b). Phenanthrene degradation in Arthrobacter sp. P1-1: initial 1,2-, 3,4and 9,10-dioxygenation, and meta- and ortho-cleavages of naphthalene-1,2-diol after its formation from naphthalene-1,2-dicarboxylic acid and hydroxyl naphthoic acids. Chemosphere 65, 2388-2394.

Shuttleworth, K. L. \& Cerniglia, C. E. (1995). Environmental aspects of PAH biodegradation. Appl Biochem Biotechnol 54, 291-302.

Smibert, R. M. \& Krieg, N. R. (1994). Phenotypic characterization. In Methods for General and Molecular Bacteriology, pp. 611-654. Edited by P. Gerhardt, R. G. E. Murray, W. A. Wood \& N. R. Krieg. Washington, DC: American Society for Microbiology.

Survery, S., Ahmad, S., Subhan, S. A., Ajaz, M. \& Rasool, S. A. (2004). Hydrocarbon degrading bacteria from Pakistani soil: isolation, identification, screening and genetical studies. Pak J Biol Sci 7, 1518-1522.

Sutherland, J. B., Freeman, J. P., Selby, A. L., Miller, D. W. \& Cerniglia, C. E. (1990). Stereoselective formation of a K-region dihydrodiol from phenanthrene by Streptomyces flavovirens. Arch Microbiol 154, 260-266.

Tortella, G. R., Diez, M. C. \& Duran, N. (2005). Fungal diversity and use in decomposition of environmental pollutants. Crit Rev Microbiol 31, 197-212.

Tsuda, M., Tan, H. M., Nishi, A. \& Furukawa, K. (1999). Mobile catabolic genes in bacteria. J Biosci Bioeng 87, 401-410. 
Vila, J., López, Z., Sabaté, J., Minguillón, C., Solanas, A. M. \& Grifoll, M. (2001). Identification of a novel metabolite in the degradation of pyrene by Mycobacterium sp. strain AP1: actions of the isolate on two- and three-ring polycyclic aromatic hydrocarbons. Appl Environ Microbiol 67, 5497-5505.

Vinas, M., Sabate, J., Espuny, M. J. \& Solanas, A. M. (2005). Bacterial community dynamics and polycyclic aromatic hydrocarbon degradation during bioremediation of heavily creosote-contaminated soil. Appl Environ Microbiol 71, 7008-7018.

Xue, W. \& Warshawsky, D. (2005). Metabolic activation of polycyclic and heterocyclic aromatic hydrocarbons and DNA damage: a review. Toxicol Appl Pharmacol 206, 73-93.

Edited by: D. Arp 